\title{
CENTER FOR AFRICAN LEGAL DEVELOPMENT CENTRE DE DÉVELOPPEMENT JURIDIQUE AFRICAIN
}

In zwangloser Folge, erhalten an dieser Stelle Institutionen, die für die Entwicklungspolitik und Entwicklungsforschung von Bedeutung sind, Gelegenheit zur Selbstdarstellung. Diesmal geben wir dem Centre for African Legal Development das Wort.

Over the past decade, comparative African law has been the object of growing interest. Requests for information on legal development in African countries were coming in from all sides: African governments, regional and international organizations, foreign investors and donors, research centres and universities. African law centers had developed in various parts of the Western Hemisphere, yet most of them narrowed their approach either geographically, or by subject. Even on the African continent itself there was a felt need for a legal center with a truly pan-African and global interest. Demands were growing for documentation in African law, traditional as well as modern, francophonic or arabic as well as anglophonic, present as well as past.

The establishment of the Center for African Legal Development-Centre de Développement Juridique Africain - or CALD has grown from the realization that research had to be carried out, and documentation assembled and provided, on such levels.

As the Organisation of African Unity and the Economic Commission for Africa had been established in Addis-Ababa, the realization grew that this city was called to become one of Africa's foremost centers, both in the political sphere and in the realm of documentation and research in the social sciences. It became apparent that Addis-Ababa was perhaps the most adequate location for an institution, specializing in documentation and research in African law.

The teacher of African law at the Free University of Brussels, Prof. Jacques Vanderlinden, who had been seconded to the Faculty of Law of the Haile Sellassie I University for many years suggested the establishment of such Center. Funds were requested from the Belgian Government and the Ford Foundation, and were granted. The Center for African Legal Development thus started its operation during the academic year 1967-1968. It is part of the Faculty of Law of the Haile Sellassie I University and works in close cooperation with the Institut de Sociologie of the Free University of Brussels. It is headed in Brussels by its founder, Prof. Jacques Vanderlinden and in Addis-Ababa by Prof. Thierry G. Verhelst.

\section{The African Legislation Project}

At the present time one of the main obstacles to comparative African legal research is the absence in Africa of fairly complete collections of Africain legislative materials.

CALD's African Legislation Project endeavors to remedy this situation by setting up in Addis-Ababa a complete collection of all African Gazettes and their supplements from 1946 till the present. The Gazettes and their supplements are reproduced on microfiches. At the same time the existing tables of contents of the Gazettes and their supplements are xeroxed and bound so as to be more easily accessible. 
CALD also acquires all existing indexes on African Legislation, such as the Documentation Législative et Administrative Africaine, published by Dakar University, the African Law Digest, published by Columbia University and Afrique Contemporaine, published by Documentation Française in Paris. Moreover, the data included in these indexes is classified by CALD under subject headings and countries which facilitates comparative legal research on African legislation, thus permitting an easier and more extensive use of the valuable data assembled in these indexes. This project should be completed by 1973. All documentation existing in CALD is available to any interested person in the form of xeroxed material or microfiche. Complete collections of microfiches are for sale.

In order to realize this programme effectively CALD had, first of all, to acquire the documentation on the basis of which all further stages of the programme could be developed. The funds granted to it enabled CALD to hire the necessary scientific and technical staff and to equip a complete microfiching laboratory. Under an agreement between Haile Sellassie I University and the Free University of Brussels, the two Universities co-operate on the African Legislation Project.

\section{The African Law Bibliography Project}

The absence of legal bibliographies dealing with specific African countries, or Africa as a whole, explains the need for an African Law Bibliography Project; the latter operates on two levels:

A. The African Law Bibliography 1947-1966 has now reached completion. The volume, which is the result of the work performed in the last three years, includes references to all books and articles published on African law from 1947 to 1966; it will be available in February 1972.

B. Yearly supplements to this volume will be prepared in conjunction with the African Law Department, School of Oriental and African Studies, University of London; the first supplements cover the years.1967-1968 and 1969. They are published in the Annual Survey of African Law.

This project is also run in conjunction with the Free University of Brussels.

\section{The African Law Library}

CALD currently endeavors to acquire in its library all the items referred to in its African Law Bibliography. This should remedy the lack of library resources often complained about in African legal milieus.

\section{Research and Publication}

Considering itself as a service to the African legal community, CALD offers its assistance both in documentation and in research to African governments, international organizations and universities. Thus, assistance was rendered to the ECAOAU Conference of African Jurists on "African Legal Process and the Individual" for which it prepared several background papers and legislative documents, and for which it drafted the report. The Centre also organizes lecture-series and conferences of its own. Publication of its research papers and of Conference proceedings is also being carried out. Witness of this is CALD's African Legal Education Conference Proceedings (1968) and the Materials on Human Rights in Africa, to be edited soon.

T.G. V. e r h elst, Co-Director, CALD. 